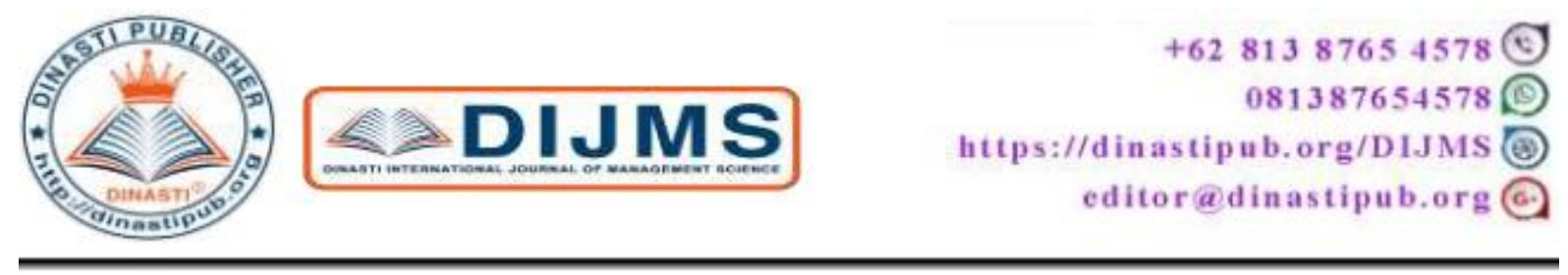

\title{
ANALYSIS OF CASH FLOW REPORTS IN ASSESSING FINANCIAL PERFORMANCE AT THE PESISIR SELATAN DISTRICT HEALTH OFFICE
}

\author{
Desmiwerita $^{1}$, Ebit Bimas Saputra ${ }^{2}$ \\ 1) Indonesian Academy of Accounting, Padang, Indonesia. \\ 2) Ekasakti University, Padang, Indonesia.
}

\begin{tabular}{|c|c|}
\hline $\begin{array}{l}\text { ARTICLE INFORMATION } \\
\text { Received: 29/11/2019 } \\
\text { Revised: 03/12/2019 } \\
\text { Issued: 10/12/2019 } \\
\text { Corresponding author: first author } \\
\text { E-mail: } \\
\text { desmiwerita03@ gmail.com } \\
\text { ebitbimas99@gmail.com }\end{array}$ & $\begin{array}{l}\text { Abstract: The Pesisir Selatan District Health Office } \\
\text { Technical Implementation Unit that has been } \\
\text { determined to apply the Financial Management Pattern } \\
\text { of the BLUD Work Unit is given in the form of } \\
\text { flexibility or flexibility to apply sound business } \\
\text { practices to optimally improve health services to the } \\
\text { community. Testing the hypothesis in this paper by } \\
\text { using a comparison of the value of the test sign with } \\
\text { the test table sign. The results of the study found (1) } \\
\text { The evaluation of cash flow performance through the } \\
\text { current liability ratio in the South Pesisir District } \\
\text { Health Office is not good, so the department is unable } \\
\text { to pay its current liabilities using only operating cash } \\
\text { flow. (2) Evaluation of cash flow performance through } \\
\text { the capital expenditure ratio shows quite good results } \\
\text { from year to year so there is no need to wait for } \\
\text { external funding such as creditors and investors. } \\
\text { However, in the last } 2 \text { years, there has been a decline } \\
\text { so external funding is needed. (3) The evaluation of } \\
\text { cash flow performance through debt expenditure ratios } \\
\text { at the South Coastal District Health Office is not good. } \\
\text { The company does not have a good ability to pay all of } \\
\text { its obligations using cash flow originating from the } \\
\text { company's normal operating activities and (4) The } \\
\text { results of the answers to the second problem found in } \\
\text { the South Pesisir District Health Office have applied to } \\
\text { account by PSAP and Government Regulation Number } \\
71 \text { of } 2010 \text { both in terms of Operating Activities, Non- } \\
\text { Financial Asset Investment Activities, Financing } \\
\text { Activities, and Non-Budget Activities. } \\
\text { Keywords: Cash Flow Statement Analysis, Financial } \\
\text { Performance, Health Office. }\end{array}$ \\
\hline
\end{tabular}




\section{INTRODUCTION}

The development of technology that continues to increase rapidly causes the need for expertise in analyzing financial statements. For this reason, managers are required to choose information in a wide network to find out the current condition of the organization and the forecast of conditions in the future. By analyzing the financial statements will help the parties concerned in selecting and evaluating information and only focus on that information.

For users of financial statements, cash flow statements are useful for assessing an organization's performance of operating, investing and financing activities and to find out which activities generate the largest funds for the company itself. Also, users of financial statements can assess the company's performance from the cash turnover of each organization's activities.

In analyzing an organization it is important to assess the net cash flow generated by the company during a certain period. Through this analysis the company is likely to be able to generate cash in the future and the company's ability to pay short-term debt obligations and long-term debt, dividends to shareholders, and can also assess whether the company's investment provides good cash flow and return for the company.

One important measure for assessing financial performance is to analyze cash flow statements. The cash flow statement is one component of the government's financial statements. The statements of cash flows describe the inflows and outflows during one period then are linked to the beginning and end of the period cash balances. Cash flows are classified based on activities and statements of cash flows associated with the realization of the budget and balance sheet.

By Statement of Government Accounting Standards (PSAP) No. 03 concerning Cash Flow Statements, it is stated that the purpose of reporting cash flows is to provide information on the sources, uses, changes in cash and cash equivalents during an accounting period and cash and cash equivalents at the reporting date. This information is presented for accountability and decision making.

Financial statements are presented to those who have an interest not to complicate and confuse their readers, but rather to assist them in making social, political, and economic decisions so that decisions made can be of higher quality. Financial statements are not the only information as a basis for decision making. There is other information besides accounting information which is also very helpful, for example, statistical reports, projections and prospectuses, news in the media, related research results, and so on. But accounting information can not be ignored and just disappear, without that information the decision taken becomes less qualified.

The main function of the financial report of the Pesisir Selatan District Health Office is to provide information to the parties concerned with the report which will be used as a basis for economic, social and political decision making.

Because not all users of financial statements understand accounting well, while they rely on financial information to make decisions, the inability to understand and interpret the financial statements, needs to be assisted with the analysis of financial performance through the analysis of financial statements that they present. Financial statement analysis is intended 
to interpret the numbers in the financial statements, how to evaluate financial statements, and how to use financial information to make decisions.

There are several methods in the analysis of financial statements. One technique that is most widely used to analyze financial statements is financial ratio analysis. There are various types of ratios that can be used to evaluate and interpret financial statements. The results of the calculation of financial ratios need to be interpreted so that an organization's financial performance can be evaluated and then certain decisions are made.

The Pesisir Selatan District Health Office Technical Implementation Unit that has been determined to apply the Financial Management Pattern of the BLUD Work Unit is given in the form of flexibility or flexibility to apply sound business practices to optimally improve health services to the community. This was done to advance public welfare and educate the nation's life, as an exception to the provisions of regional financial management in general.

As an accounting entity, UPT South Pesisir District Health Office that implements the BLUD financial management pattern is required to carry out accounting and prepare financial reports. An accounting entity is a government unit that uses budget/goods users and is therefore obliged to carry out accounting and prepare financial statements to be combined with the reporting entity, (PSAP Number 11 Paragraph 06 concerning Consolidated Financial Statements).

The reality of the current condition is that the accounting basis used by the UPT of the South Coastal District Health Office is not accrual-based and is still cash-based towards accruals. Also, the UPT of the South Coastal District Health Office does not yet have an accounting system in preparing its financial statements. For this reason, this research will design an accounting system, specifically the preparation of accrual-based financial reports, in connection with the stipulation of the UPT South Pesisir District Health Office that has implemented the Financial Management Pattern of the Regional Public Service Agency (PPK BLUD) so that it can be accounted for by applicable regulations.

In connection with the background above, the authors take the following title: "Analysis of Cash Flow Reports in Assessing Financial Performance at the South Coastal District Health Office".

\section{LITERATURE REVIEW}

1. Cash Flow Statement

According to Halim (2012) the cash flow statement presents information on cash receipts and disbursements and cash equivalents during certain periods which are classified based on operating activities, investment in non-financial assets, financing and non-financing. While cash flow according to the Indonesian Institute of Accountants (2011: 2.2) "cash flow is the inflow and outflow of cash or cash equivalents." From the information above it can be seen that the cash flow statement can help show how the cash changes that occur in a company are reported with the same relevance. certain period.

Preparation of cash flow statements according to the Indonesian Institute of Accountants (2011: 2.3) "Cash flow statements must report cash flows for a certain period and are classified according to operating, investing and financing activities". 

a. Cash Flow From Operating Activities
b. Cash Flow From Investment Activities
c. Cash Flow From Funding Activities

\section{Cash Flow Statement Analysis in Assessing Company Performance}

One analysis of financial performance using cash flow statement information is the analysis of cash flow statement ratios. The analysis of cash flow statements uses components in the cash flow statement and balance sheet components and income statement as a ratio analysis tool. The cash flow statement ratio analysis tool is needed to assess the Company's financial performance, among others (Darsono, 2015):

a. The ratio of operating cash flows to Current Liabilities

The cash flow ratio calculates the ability of cash in paying current liabilities. This ratio is obtained by dividing cash by current liabilities.

Cash Flow $=\frac{\text { Amount of Cash }}{\text { The obligation }}$

b. The ratio of operating cash flows to cash to interest coverage (CKB).

This ratio is used to determine the company's ability to pay interest on existing debt. This ratio is obtained with cash plus interest payments, and tax payments divided by interest payments.

$\mathrm{CKB}=\underline{\text { Cash }+ \text { Interest }+ \text { Tax }}$

Flower

c. Cash Coverage to Current Debt (CKHL) Ratio

This ratio measures the company's ability to pay smooth debt based on net cash. This ratio is obtained by cash plus cash dividends divided by current debt.

CKHL $\quad=\underline{\text { Cash }+ \text { Cash Deviations }}$

Current liabilities

d. Operating cash flow ratio to Capital Expenditures (PM)

This ratio is used to measure the available capital for investment and payment of the existing debt. This ratio is obtained by cash divided by capital expenditure.

$\mathrm{PM} \quad=\underline{\text { Cash }}$

Fixed assets

e. Operating cash flow ratio to Total Debt $(\mathrm{TH})$

This ratio shows the period of debt repayment by the company assuming all operating cash flows are used to pay debts. This ratio is obtained from cash divided by total debt. By knowing this ratio, we can analyze in time some companies will be able to pay debts using the cash generated from the company's activities.

$\mathrm{TH} \quad=\underline{\mathrm{Cash}}$

Total Amoun of debt

f. The ratio of operating cash flows to Coverage of Funds Flow (CAD)

This ratio is used to determine the company's ability to generate cash to pay commitments (interest, taxes, and preferred dividends). This ratio is obtained by profit before tax and interest (EBIT) divided by interest, tax adjustments, and preferred dividends.

CAD $=\underline{\text { Interest }+ \text { Adjustment }}$ 


\section{Tax + Preferred Stock}

\section{Financial Performance}

Financial performance is an analysis conducted to see the extent to which a company has carried out the company's operational activities by using the rules of financial implementation properly and correctly. Such as by making a financial report that meets the standards and provisions in SAK (Financial Accounting Standards) or GAAP (General Accepted Accounting Principle) (Fahmi, 2013: 2). The success of a company in achieving its goals and meeting the needs of the community is very dependent on the performance of the company and company managers in carrying out its responsibilities.

\section{RESEARCH METHODS}

The research methods are as follows: Field Research and Library Research. Types and sources of data are primary data and secondary data. The population in this study is the Cash Flow Report of the South Coastal Regency. While the sample withdrawal criteria were taken from the South Pesisir Regency Health Office Cash Flow Report for the last 5 (five) years, namely 2013 and 2017 and testing the hypothesis in this paper by using a comparison of the value of the test sign with the test table sign.

\section{FINDINGS AND DISCUSSION}

Cash Flow Reports in Assessing Financial Performance at the South Pesisir Regency Health Office

\section{Operating Cash Flow Ratio To Current Liabilities}

The following financial performance is presented based on the ratio of operating cash flow to current liabilities at the South Pesisir District Health Office:

Table 1. The ratio of Operating Cash Flow to Current Liabilities at the South Pesisir District Health Office

\begin{tabular}{c|c|c|c}
\hline Current & Cash & Payable & Ratio (\%) \\
\hline 2013 & 119.372 .500 & 78.286 .500 & 1,5248 \\
\hline 2014 & 113.042 .554 & 76.286 .500 & 1,4818 \\
\hline 2015 & 120.322 .764 & 70.286 .500 & 1,7119 \\
\hline 2016 & 132.874 .277 & 68.286 .500 & 1,9458 \\
\hline 2017 & 121.141 .198 & 68.286 .500 & 1,7740 \\
\hline
\end{tabular}

Source: Pesisir Selatan Health Service, 2018

The results of the ratio analysis show that the highest current liability ratio occurred in 2016 and decreased in 2017 with a difference of 0.1718 compared to 2016. In this study, the current liability ratio figures in 2013, 2014 and until 2017 are in the ratio above 1 , it can be concluded that the current liability ratio at the South Pesisir Selatan District Health Office is not good, so that the department is unable to pay its current liabilities using only operating cash flow.

Another study conducted by Regina (2013) found that the financial condition was in a bad position so that it was unable to pay off its current liabilities using only operating 
cash flow. The similarity of this research with previous researchers is that they are both unable to pay off their current liabilities using only operating cash flow. The difference between this researcher and previous research is the different location of the study and the time of the study.

Research conducted by Setiawan (2016) shows that the ratio of cash to current debt ratio of the three cement industries which has the highest cash to debt ratio is PT Indocement Tunggal Perkasa Tbk of 1.82 times while companies that have a cash coverage ratio of the lowest current debt is PT Semen Gresik Tbk of 0.45 times. The equation of this study with previous research is equally measuring cash flow in order to assess financial performance. While the difference is the difference between this researcher and previous research is different research locations and time of the study.

The ratio of cash coverage to the current debt is the ratio to measure the company's ability to pay current debt-based on net operating cash flow. This ratio is obtained by operating cash flow plus cash dividends divided by current debt. The higher the ratio of cash coverage to current debt, the better the company's ability to pay the current debt, and vice versa, the lower the ratio of cash to debt coverage, the lower the company's ability to pay current debt.

\section{The ratio of Operating Cash Flow to Capital Expenditures}

The following financial performance is presented based on the ratio of operating cash flow to capital expenditure in the South Coastal District Health Office:

Table 2. The ratio of Operating Cash Flow To Capital Expenditures at the South Pesisir Regency Health Office

\begin{tabular}{c|c|c|c}
\hline Current & Cash & Fixed assets & Ratio (\%) \\
\hline 2013 & 119.372 .500 & 679.460 .693 & 0,1757 \\
\hline 2014 & 113.042 .554 & 672.871 .593 & 0,1680 \\
\hline 2015 & 120.322 .764 & 660.680 .471 & 0,1821 \\
\hline 2016 & 132.874 .277 & 121.710 .809 .170 & 0,0011 \\
\hline 2017 & 121.141 .198 & 102.681 .198 .891 & 0,0012 \\
\hline
\end{tabular}

Source: Pesisir Selatan Health Service, 2018

The results of the ratio analysis show that the capital expenditure ratio showed quite good results from 2013 of 0.1757 , in 2014 of 0.1680 and 2015 of 0.1821 so there was no need to wait for external funding such as creditors and investors. However, in 2016 and 2017 it decreased to 0.0011 and 0.0012 , so external funding is needed.

Another study conducted by Susanti Tudje (2017) found that the ratio of capital expenditure showed quite good results so that there was no need to wait for external funding such as creditors and investors. However, in the last year, it has declined to the point where external funding is needed. The equation of this study with previous research is equally measuring cash flow in order to assess financial performance. While the difference is the difference between this researcher and previous research is different research locations and time of the study. 
Research conducted by Setiawan (2016) shows that the capital expenditure ratio of the three cement industry companies which has the highest capital expenditure ratio is PT Indocement Tunggal Perkasa Tbk of 7.78 times while the company that has the lowest capital expenditure ratio is PT Semen Cibinong Tbk 5.14 times. The equation of this study with previous research is equally measuring cash flow in order to assess financial performance. While the difference is the difference between this researcher and previous research is different research locations and time of the study.

The capital expenditure ratio is the ratio used to measure the available capital for investment and payment of the existing debt. This ratio is obtained by cash divided by capital expenditure. The higher the ratio of capital expenditure in a company, shows that the company does not spend much capital to buy fixed assets. Vice versa, the lower the ratio of capital expenditure in a company, the company has spent a lot of capital to buy fixed assets.

\section{Operating Cash Flow Ratio To Total Debt}

The following financial performance is presented based on the ratio of operating cash flow to total debt at the South Pesisir District Health Office:

Table 3. Operating Cash Flow Ratio to Total Debt at the South Coastal District Health Office

\begin{tabular}{c|c|c|c}
\hline Current & Cash & Total Amoun of debt & Ratio (\%) \\
\hline 2013 & 119.372 .500 & 159.407 .198 & 0,7489 \\
\hline 2014 & 113.042 .554 & 169.407 .198 & 0,6673 \\
\hline 2015 & 120.322 .764 & 149.407 .198 & 0,8053 \\
\hline 2016 & 132.874 .277 & 169.407 .198 & 0,7843 \\
\hline 2017 & 121.141 .198 & 179.407 .198 & 0,6752 \\
\hline
\end{tabular}

Source: Pesisir Selatan Health Service, 2018

The results of the ratio analysis show that the debt expenditure ratio in the South Pesisir District Health Office is not good, because the total debt ratio is 2013-2017 is below 1 but the highest number is in 2015. It can be said, that the company does not have a good ability in paying all its obligations using cash flow from the normal operations of the company.

Another study conducted by Susanti Tudje (2017) found that the company did not have a good ability to pay all of its obligations using cash flow originating from the normal activities of the company's operations. The equation of this study with previous research is equally measuring cash flow to assess financial performance. While the difference is the difference between this researcher and previous research is different research location and time of study.

The ratio of total debt shows the period of debt repayment by the company assuming all operating cash flow is used to pay debts. This ratio is obtained from operating cash flow divided by total debt. By knowing this ratio, it can be analyzed how long the company will be able to pay debts using cash flow generated from operational 
activities. The shorter the time of the company to pay the debt, the better the company's ability to pay debts, conversely the longer the term of repaying the debt, the lower the company's ability to pay debts.

Research conducted by Setiawan (2006) shows that the total debt ratio of the three cement industries which has the highest total debt ratio is PT Semen Gresik Tbk by 22\% while the company that has the lowest total debt ratio is PT Semen Cibinong Tbk by $3 \%$.

Analysis of Cash Flow Reports at the Pesisir Selatan District Health Office By Government Accounting Standards Statement (PSAP) No. 03 and Government Regulation Number 71 of 2010

The following is an analysis of cash flow statements presented to the South Coastal District Health Office:

Table 4. Government in the South Coastal District Health Office

\begin{tabular}{c|c}
\hline SAP & Pesisir Selatan District Health Office \\
\hline Operating Activities & Has been implemented $(\sqrt{ })$ \\
Asset Investment Activities & Has been implemented $(\sqrt{ })$ \\
Non-financial & Has been implemented $(\sqrt{ })$ \\
Financing Activities & Has been implemented $(\sqrt{ })$ \\
Non-budget activities & Has been implemented $(\sqrt{ })$ \\
\hline
\end{tabular}

Source: Self-professed Data, 2018

The table above shows that in its application the Pesisir Selatan District Health Office has conducted operational activities by SAP, Asset Investment Activities by SAP, nonfinancial by SAP, financing activities by SAP and non-budget activities by SAP. Another result found that the Pesisir Selatan District Health Office had implemented a cash flow statement by PSAP both in terms of Operating Activities, Non-Financial Asset Investment Activities, Financing Activities and Non-Budgeting Activities.

Also, the following presents the differences in the application of SAP with the South Coastal District Health Office:

Table 5. Differences in Application of SAP, Government Regulation Number 71 of 2010 with the South Coastal District Health Office

\begin{tabular}{|c|l|c|c|}
\hline \multirow{2}{*}{ No } & \multicolumn{2}{|c|}{ PSAP Implementation } & \\
\cline { 2 - 3 } & $\begin{array}{c}\text { SAP and Government } \\
\text { Regulation Number 71 of } \\
\end{array}$ & \multicolumn{1}{|c|}{ 2010 } & Pesisir Selatan District Health Office \\
Sign \\
\hline 1 & Operating Activities & Has been implemented & + \\
2 & Asset Investment Activities & Has been implemented & + \\
3 & Non-financial & Has been implemented & + \\
4 & Financing Activities & Has been implemented & + \\
5 & Non-budget activities & Has been implemented & + \\
\hline
\end{tabular}

Source: Pesisir Selatan Health Service, 2018 
Based on the table above it can be seen that the South Pesisir Selatan District Health Office has implemented accounting by PSAP both in terms of Operating Activities, Nonfinancial Asset Investment Activities, Financing Activities and Non-budget Activities. Based on the test of the sign found (XY) which gives $h$ arithmetic $=5$, for the least sign is a negative sign, with $\mathrm{N}=5$ and $\alpha=0.05$ then the count $=\mathrm{h}(5 \%: 5)=0.01$ rounded to 0 , from the sign value table found $\mathrm{h}$ table $=0$, the decision reject $\mathrm{Ha}$ and accept $\mathrm{HO}$ because $\mathrm{h}$ count $=0$ and table $\mathrm{Ha}=0$, so it can be concluded that the application of cash flow statement of the South Pesisir Regency Health Service is by SAP.

Research conducted by Setiawan (2016), the application of a cash flow accounting system at the Bandung Abdi Angkasa Raya Company is by Indonesian GAAP. Another study conducted by Regina (2013) found that companies had implemented a cash flow accounting system by Indonesian GAAP.

The cash flow adequacy ratio is the ratio used to measure a company's ability to provide cash to meet its liabilities within the next 5 years. This ratio is obtained by profit before tax and interest minus tax payments minus interest-capital expenditure payments divided by the average debt that is due annually for five years.

\section{CONCLUSION AND SUGESTION}

\section{Conclusions}

Based on the formulation of problem number 1 namely cash flow problems at the South Coastal District Health Office are:

1. Evaluation of cash flow performance through the ratio of financial needs in the South Pesisir Selatan District Health Office is not good so that the department is unable to pay its current needs just by using operating cash flow only.

2. Assessment of cash flow performance through the ratio of capital expenditure results that are quite good from year to year, no need to wait externally such as creditors and investors. However, in the last 2 years, it needs to be replaced from outside.

3. Assessment of cash flow performance through expenditure ratios at the South Pesisir Selatan District Health Office. The company does not have a good ability to pay all parties by using cash flow that is removed from the normal operation of the company.

The results of answering the formulation of the second problem were found in the Pesisir Selatan District Health Office having requested approval by PSAP and Government Regulation Number 71 of 2010 both in terms of Operational Activities, Non-Financial Asset Investment Activities, Financing Activities, and Non-Budget Activities.

\section{Sugestion}

Based on the conclusions presented above, suggestions can be made that are expected to add information and help the South Pesisir District Health Office, or other interested parties. To achieve the goals set by the company and improve company performance, it is recommended for the South Coastal District Health Office to further increase company cash, especially in operating activities which are the main activity of the company and reduce the amount of debt so that the company's cash flow going forward. 
The results showed the results of the South Pesisir Selatan District Health Office had applied to the account by PSAP both in terms of Operational Activities, Non-Financial Asset Investment Activities, Financing Activities, and Non-Budget Activities, therefore agencies should be able to maintain and further improve the quality of the agency's financial statements.

\section{REFERENCE}

Agussalim Manguluang, 2010, Statistics, Ekasakti Press, Padang

Darsono, 2015. Practical Guidelines for Understanding Financial Statements, Yogyakarta

Dwi Prastowo and Rifka Julianti. 2013. Analysis of Financial Statements. Jakarta: Earth Literacy

Eugene F. Brigham and Joel F. Houstom, 2014, Financial Management, Jakarta: Erlangga

Fahmi, Irham. 2013. Analysis of Financial Statements. Bandung: Alfabeta

Fred Weston and Thomas E. Copeland. 2012. Fundamentals of Financial Management, Erlangga

Halim, 2012, Regional Financial Accounting (Public Sector Accounting), Jakarta: Salemba Empat

Harahap Sofyan S, 2013, Critical Analysis of Financial Statements, Edition One, PT. Raja Grafindo Persada: Jakarta.

Harjito and Martono, 2014. Financial Management. Second Edition, First Printing, EKONISIA Publisher, Yogyakarta

Hery S, Accounting Theory, 2015, Salemba Empat: Jakarta

Indonesian Accounting Association, 2011, Statement of Financial Accounting Standards, Salemba Empat: Jakarta

Mudrajad, 2011, Research Methods for Business and Economics, Erlangga: Jakarta

Ormiston. 2012. Understanding Financial Statements. Seventh Edition, Index. Jakarta (translation).

Sutrisno, 2013, Financial Management Theories, Concepts and Applications, Yogyakarta: Economics

Syamsudin. 2014. Financial Management. Yogyakarta: BPFE

Wisnu Widjaya and Moh. Badjuri. 2012. Practical Guidelines for Auditing Accountants by Public Accountants. Fourth edition. Jakarta: Salemba Empat 